\title{
COVID-19 and Emerging Zoonosis - The Clock is Counting Down: Time for Closer Collaboration between Veterinary and Human Medicine
}

\author{
Beatriz do Vale ${ }^{1}$, Ana Patrícia Lopes ${ }^{1,2}$, Maria da Conceição Fontes ${ }^{1,2}$, Mário \\ Silvestre ${ }^{2,3}$, Luís Cardoso ${ }^{1,2}$, Ana Cláudia Coelho ${ }^{1,2, *}$ \\ ${ }^{1}$ Department of Veterinary Sciences, University of Trás-os-Montes e Alto Douro, Portugal \\ ${ }^{2}$ Animal and Veterinary Research Centre, University of Trás-os-Montes e Alto Douro, Portugal \\ ${ }^{3}$ Department of Zootechnics, University of Trás-os-Montes e Alto Douro, Portugal
}

\section{Review Article \\ Volume 6 Issue 1}

Received Date: February 11, 2021

Published Date: April 07, 2021

DOI: 10.23880 /oajvsr-16000209

*Corresponding author: Ana Cláudia Coelho, Department of Veterinary Sciences, School of Agrarian and Veterinary Sciences (ECAV), University of Trás-os-Montes e Alto Douro (UTAD), 5000-801, Vila Real, Portugal, Email: accoelho@utad.pt ; ORCID: 0000-0002-7196-4179

\section{Abstract}

The coronavirus disease 2019 (COVID-19) pandemic caused by severe acute respiratory syndrome coronavirus 2 (SARS-CoV-2) quickly spread from China and crossed international borders. For the first time in this century, the world is facing a nightmare of 2 million deaths due to the respiratory pandemic by January 2021. Most of the emerging or re-emerging pathogens are likely to be zoonotic, and SARS-CoV-2 potentially has an animal origin, a circumstance that is a public health concern and a burden on any country's economy. Greater awareness and understanding of potential disease promoters and effective disease surveillance systems are crucial for detecting outbreaks of emerging zoonotic diseases as quickly as possible. In order to achieve this goal, there is an urgent need for a One Health approach between human and veterinary medicine. Indeed, the One Health approach, along with all the lessons learned from previous coronavirus threats (SARS- and MERS-CoVs), as well as the advance of science is essential for dealing with emerging zoonosis, including COVID-19. It is urgent to create task forces, networks and all types of collaborations between human and veterinary medicine to prevent future pandemic events.

Keywords: COVID-19; Emerging Zoonosis; One Health; Public Health; SARS-Cov-2

Abbreviations: COVID-19: Coronavirus Disease 2019; Covs: Coronaviruses; SARS-Cov-2: Severe Acute Respiratory Syndrome Coronavirus 2; SARS: Severe Acute Respiratory Syndrome; MERS: Middle East Respiratory Syndrome; MERSCov: Middle East Respiratory Syndrome Coronavirus; HIV: Human Immunodeficiency Virus; AIDS: Acquired Immune Deficiency Syndrome; IBV: Infectious Bronchitis Virus; FIPV: Feline Infectious Peritonitis Virus.

\section{Introduction}

The last two decades have shown a worrying situation in the field of infectious diseases, since new pathogens emerged; old pathogens re-emerged after a long absence from a certain population; or have occurred in a previously non-recognized population or geographical area for the diseases they cause; and zoonotic agents, some of them neglected, are still present. In fact, since the beginning of the 21st century, numerous outbreaks of bacterial and viral zoonotic diseases have occurred worldwide [1]. However, the main outbreak to date has been COVID-19. Indeed, after its first outbreak in China, COVID-19 caused by SARSCoV-2 has quickly spread and crossed international borders, reaching the pandemic status [2]. Coronaviruses (CoVs) 


\section{Open Access Journal of Veterinary Science \& Research}

are positive-sense RNA viruses which belong to the family Coronaviridae. Taxonomically, SARS-CoV-2 is a member of the order Nidovirales, the genus Betacoronavirus and subgenus Sarbecovirus [3]. Coronaviruses have long been known in veterinary medicine. Primarily, they mainly caused enzootic infections in birds and mammals. However, in recent decades, they have crossed the barrier of host species and have also demonstrated to be capable of infecting humans, both in the upper and lower respiratory tracts, causing respiratory disease of varying degrees, such as bronchitis and pneumonia [4]. The outbreak of Severe Acute Respiratory Syndrome (SARS), in 2003, and of Middle East Respiratory Syndrome (MERS), in 2012, demonstrated pathogenicity and mortality of coronaviruses in humans and are examples of viruses that have crossed the species barrier [5]. This minireview aims to emphasize the urgent need for collaboration between veterinary and human medicine through the One Health strategy for the prevention and control of COVID-19, as well as other emerging zoonosis.

\section{Factors Associated to the Emergence of Zoonosis}

The emergence and maintenance of zoonosis are multifactorial and affected by dynamic interactions among the host, aetiological agent and environment [6-8]. Regarding human activity and travel, globalization has been considered a factor in increasing the transfer of pathogens to pristine areas, such as tropical forests [9]. Tourism and travel to exotic places have steadily increased over recent years. Although they represent an important economic sector for any country, several health issues have been reported, as the outbreak of Middle East respiratory syndrome coronavirus (MERS-CoV) in South Korea caused by a returnee from the Middle East [10]. Moreover, the transmission of agents of airborne emerging diseases due to commercial airline networks has also been described Mangili A, et al. [11]. One example is the outbreak of SARS in 2003, whose pathogen was disseminated from China to at least 17 countries within a week [7].

History has shown that large-scale epidemics have followed large-scale human migratory movements. Some examples include the Black Death (caused by Yersinia pestis), cholera (Vibrio cholerae), SARS and malaria (Plasmodium falciparum) [12]. Millions of people and animals travel the world annually. The movement of people, animals and food (of animal and vegetable origin) may quickly disseminate pathogenic agents worldwide [13], since they can travel not only inside a sick host, but also by apparently healthy but infected carriers. Before COVID-19 outbreak, it was possible to travel to any part of the world within a few hours and thousands of air journeys were made daily. In addition, trip duration is shorter than the incubation periods of many diseases (especially viral ones) [14], a circumstance which increase the odds of a rapid distribution of infectious agents into new areas. In fact, the last 10 years have shown that zoonotic diseases such as Chikungunya, Dengue, Ebola, MERS, and SARS may have the potential to spread across borders due to rapid human mobility via the global airline network [7]. Since last year, the world assists to the swiftly spread of COVID-19 across the globe, and travel restrictions and border control measures, like never seen before, have been enforced to limit the spread of the outbreak [15].

Pet ownership is another recognized factor. It is known that there are many health benefits, including physical, mental and emotional improvements, linked to pet ownership. New companion animals such as reptiles, birds or insects can also be responsible for zoonotic infections. Additionally, there is an increasing trend (particularly in high-income countries) to breed and maintain wild animals as pets, a situation which can lead to many infectious agents crossing the species barrier into humans [16]. SARS-CoV-2 has been detected in naturally infected dogs and cats in households, most of which lived in close contact with infected humans [17]. Understanding risk factors associated with this scenario and their potential to infect other species requires urgent investigation [18].

The global trade of animals (i.e. pets, livestock and wildlife) and products of animal origin has also been related to the dissemination of non-zoonotic diseases, such as foot and mouth disease, classical and African swine fevers, and zoonosis like brucellosis [19], human monkeypox in North America and H5N1 in the United Arab Emirates [12]. The global trade of illegally imported products of animal origin, and non-compliant or the absence of food and animal control allow vector insects, or other infected animals, to transmit pathogens that can be introduced into areas where there is no host resistance or native predators, and to reintroduce them into previous officially-free regions. Consequently, naïve populations can face large outbreaks and remarkable socioeconomic costs [19]. Several factors influence the ability of a new microorganism to become a public health threat. It is considered that viruses cause about $45 \%$ of emerging human diseases. RNA viruses, as SARS-CoV-2, are prone to emerge due to their high rates of replication and mutation, which may produce novel variants responsible for the emergence and re-emergence of infectious diseases [20]. As a consequence, new variants emerge as is the case of the emergent SARS-CoV-2 B.1.1.7 lineage in the United Kingdom defined by a novel set of spike mutations [21,22].

Anthropogenic practices associated with agricultural production or industrial processes have been identified and are linked to the spread of pathogens, creating new ecological niches and exposing human and animal populations to them [23]. Agricultural expansion contributes to encroachment into wildlife habitats, which causes changes in the ecosystem 


\section{Open Access Journal of Veterinary Science \& Research}

and implies close proximity of humans and livestock to wildlife and vectors. Such circumstances are responsible for the potential spill over of wildlife pathogens in livestock and humans [24]. Deforestation has accelerated exponentially since the beginning of the 20th century, mainly due to human population growth, agricultural intensification and political and economic interests. This is inextricably linked to habitat destruction and a drastic reduction in biodiversity, since the population of natural predators is no longer sufficient to control rodents, insects and other potential transmitters of infectious agents. This may affect host and pathogen dynamics, forcing reservoirs of zoonotic diseases to become closer to potentially susceptible animal and human populations [25]. One example is the occurrence of the Nipah virus outbreak in Malaysia in the late 1990s, affecting pigs and humans [26].

Increased incidence of zoonosis and/or vector-borne diseases (as well as changes in their transmission pattern) is closely related to drastic changes in the environment and ecosystems caused by climate change associated with global warming [27]. The occurrence of extreme weather events such as heat waves, cold spells, droughts or floods may favour the increase of vectors and their movement from endemic areas, in addition to decreasing their natural predator population, and it have influenced the development, behaviour and survival of vectors as well as the dynamics of pathogen transmission [28].

\section{Building the Bridge between Veterinary and Human Medicine}

Global health challenges need an innovative and cooperative approach between human and animal health authorities. In the late 19th century and early 20th century, physicians as Rudolf Virchow and William Osler explained that animal and human health were inextricably linked [29]. Moreover, Virchow indicated the absence of boundaries between human and animal health, and emphasized their crossing lines [30]. Currently, the relationship among humans, animals and environment has gained importance associated with COVID-19 concerns [2]. One of the main problems of emerging and re-emerging diseases is their control, since they are sporadic and unpredictable, often appearing from unexpected reservoirs [26]. Since 60 to $80 \%$ of the new human infections likely originated in animals, research and control measures aimed at emerging/ remerging zoonotic diseases should include appropriate veterinary support [31] (Table 1). Their impact is greater in developing countries because of risk factors, such as the lack of medical and human resources to tackle disease outbreaks and the high population growth and abundance of vectors and reservoirs of pathogens. Additionally, a high number of people with a compromised immune system due to the human immunodeficiency virus (HIV)/acquired immune deficiency syndrome (AIDS) or parasitic diseases, a dependence on animals as the main source of livelihood, low socio-economic status and hygienic deficits are considered important risk factors [7].

\begin{tabular}{|c|c|c|c|}
\hline Disease & Etiology & Animal host & Mode of transmission \\
\hline \multirow{2}{*}{ Anthrax } & Bacillus anthracis & $\begin{array}{c}\text { Cattle, horses, sheep, } \\
\text { pigs, dogs, bison, } \\
\text { elks, white-tailed } \\
\text { deer, goats, and mink }\end{array}$ & $\begin{array}{c}\text { Cutaneous route; inhalation; infected } \\
\text { animals or animal products; ingestion } \\
\text { (undercooked or raw meat or dairy } \\
\text { products) }\end{array}$ \\
\hline Tuberculosis & $\begin{array}{c}\text { Mycobacterium bovis, Mycobacterium } \\
\text { caprae, Mycobacterium microti }\end{array}$ & $\begin{array}{c}\text { Cattle, sheep, swine, } \\
\text { deer, wild boars, } \\
\text { camels, and bison }\end{array}$ & Inhalation of droplets \\
\hline Brucellosis & $\begin{array}{c}\text { Brucella abortus, Brucella } \\
\text { melitensis,Brucella suis,Brucella canis }\end{array}$ & $\begin{array}{c}\text { Cattle, goats, sheep, } \\
\text { pigs and dogs }\end{array}$ & $\begin{array}{c}\text { Contact with infected tissues or fluids; } \\
\text { ingestion (raw milk or dairy products); } \\
\text { contamination of a fresh wound with } \\
\text { infected matter from animals (blood, } \\
\text { urine, aborted fetuses and placenta); } \\
\text { accidental needle-stick puncture with } \\
\text { Brucella B19 vaccine while vaccinating } \\
\text { animals }\end{array}$ \\
\hline
\end{tabular}




\section{Open Access Journal of Veterinary Science \& Research}

\begin{tabular}{|c|c|c|c|}
\hline Leptospirosis & Leptospira interrogans & $\begin{array}{l}\text { Wild and domestic } \\
\text { animals including } \\
\text { pet dogs }\end{array}$ & $\begin{array}{l}\text { Cutaneous route (skin abrasions or } \\
\text { exposed mucous membranes); contact } \\
\text { with infected matter (urine or tissues) } \\
\text { from animals (usually rodents); contact } \\
\text { with surface water, soil or plants } \\
\text { contaminated with the leptospirosis } \\
\text { bacteria from the urine of infected } \\
\text { animals }\end{array}$ \\
\hline Lyme disease & Borrelia burgdorferi & $\begin{array}{l}\text { Cats, dogs, and } \\
\text { horses }\end{array}$ & Bite from an infected tick \\
\hline Salmonellosis & Salmonella enteritidis & $\begin{array}{l}\text { Poultry, domestic } \\
\text { and wild animals }\end{array}$ & $\begin{array}{c}\text { Ingestion (raw or improperly cooked food } \\
\text { of animal origin, mainly meat, poultry, } \\
\text { eggs and milk) }\end{array}$ \\
\hline Ehrlichiosis & $\begin{array}{c}\text { Anaplasma, } \\
\text { phagocytophilum,Ehrlichia } \\
\text { ewingii,Ehrlichia } \\
\text { chaffeensis,Ehrlichia } \\
\text { canis,Neorickettsia sennetsu } \\
\end{array}$ & $\begin{array}{l}\text { Sheep, cattle, deer, } \\
\text { dogs and cats }\end{array}$ & Bite from an infected tick \\
\hline \multicolumn{4}{|c|}{ Viral Zoonosis } \\
\hline Rabies & $\begin{array}{l}\text { Rabies virus, Genus-Lyssavirus, } \\
\text { Family—Rhabdoviridae }\end{array}$ & \begin{tabular}{|l} 
Cattle, horses, cats, \\
dogs, bats, monkeys, \\
wolves, skunks, \\
rabbits, and coyotes \\
\end{tabular} & $\begin{array}{l}\text { Bite or scratch from an infected animal; } \\
\text { direct contact between infected saliva and } \\
\text { human mucosa or fresh skin wounds }\end{array}$ \\
\hline $\begin{array}{l}\text { Avian influenza } \\
\text { A(H5N1) and } \\
\text { A(H7N9) }\end{array}$ & $\begin{array}{l}\text { Influenza A virus, Genus- } \\
\text { Alphainfluenzavirus, Family- } \\
\text { Orthomyxoviridae }\end{array}$ & $\begin{array}{l}\text { Ducks, chickens, } \\
\text { turkeys,, dogs, cats, } \\
\text { pigs, whales, horses, } \\
\text { seals, and wild, birds } \\
\end{array}$ & $\begin{array}{l}\text { Direct or indirect contact with sick or } \\
\text { dead birds; contaminated products such } \\
\text { as faecal material }\end{array}$ \\
\hline Rift Valley fever & $\begin{array}{l}\text { Rift Valley fever virus, fever virus, } \\
\text { Genus-Phlebovirus, } \\
\text { Family—Bunyaviridae }\end{array}$ & $\begin{array}{l}\text { Buffaloes, camels, } \\
\text { cattle, goats, and } \\
\text { sheep }\end{array}$ & $\begin{array}{l}\text { Bite of infected mosquitoes or other } \\
\text { insects; contact with infected tissues or } \\
\text { fluids; contact with the aborted material } \\
\text { from infected animals; cutaneous route } \\
\text { (through skin abrasions); inhalation of } \\
\text { aerosols }\end{array}$ \\
\hline $\begin{array}{l}\text { Ebola virus } \\
\text { disease (Ebola } \\
\text { hemorrhagic } \\
\text { fever) }\end{array}$ & $\begin{array}{c}\text { Ebola virus, Genus_Ebolavirus, } \\
\text { Family_Flaviviridae }\end{array}$ & $\begin{array}{l}\text { Monkeys, gorillas, } \\
\text { chimpanzees, apes, } \\
\text { and wild antelopes }\end{array}$ & $\begin{array}{l}\text { Introduced by contact with infected } \\
\text { tissues or fluids; spread through } \\
\text { human-to-human transmission (direct } \\
\text { contact between broken skin or mucous } \\
\text { membranes and infected fluids and } \\
\text { tissues); burial ceremonies }\end{array}$ \\
\hline Dengue fever & $\begin{array}{l}\text { Dengue virus, Genus-Flavivirus, } \\
\text { Family-Flaviviridae }\end{array}$ & Monkeys and dogs & $\begin{array}{c}\text { Bite of infective female Aedesmosquito (A. } \\
\text { aegypti; A. albopictus) }\end{array}$ \\
\hline Zika fever & $\begin{array}{l}\text { Zika virus, Genus-Flavivirus, } \\
\text { Family-Flaviviridae }\end{array}$ & Apes and monkeys & $\begin{array}{c}\text { Bite of an infected Aedes mosquito ( } A \text {. } \\
\text { aegypti; } A \text {. albopictus) }\end{array}$ \\
\hline West Nile fever & $\begin{array}{c}\text { West Nile virus, Genus-Flavivirus, } \\
\text { Family_Flaviviridae }\end{array}$ & $\begin{array}{l}\text { Horses, birds, and } \\
\text { reptiles }\end{array}$ & $\begin{array}{l}\text { Bite of an infected Culex mosquito. } \\
\text { Mosquitoes become infected when they } \\
\text { feed on infected birds }\end{array}$ \\
\hline $\begin{array}{c}\text { Severe acute } \\
\text { respiratory } \\
\text { syndrome (SARS) }\end{array}$ & SARS-CoV, Genus-Coronavirus & $\begin{array}{c}\text { Bats, dogs, cats, } \\
\text { ferrets, minks, tigers, } \\
\text { and lions }\end{array}$ & Inhalation of droplets \\
\hline
\end{tabular}

Table 1: Bacterial and viral zoonotic diseases, their etiological agents, animal hosts and mode of transmission $[6,8]$. 


\section{Open Access Journal of Veterinary Science \& Research}

A One Health integrative approach for COVID-19 and new zoonosis must be implemented in order to develop epidemiological surveillance and to establish disease control mechanisms to limit zoonotic transmission [2]. Long-term veterinary experience with infections caused by CoVs, such as infectious bronchitis virus (IBV) in poultry, feline infectious peritonitis virus (FIPV) or swine CoVs, needs to be included for a better understanding of the origin and spread of SARS-CoV-2. The same is true regarding the use of animal models to study vaccines for humans [2,32]. Among the distinctive areas of action to anticipate ultimate threats caused by biological agents, four of them stand out and can be applied to SARS-CoV-2. The first one is related to the discovery of pathogenic agents through continuous longitudinal surveillance of wildlife and domestic animals, considering the animal origin of SARS-CoV-2 and its spill over into humans [2]. The second one refers to the quantifiable identification of the risk that a microorganism as SARSCoV-2 may represent to humans as well as their transmission pathway to humans and other animals [33]. The third one is the ability to respond adequately to COVID-19 outbreaks by strengthening countries skills to detect them with effective rapid diagnostic tests [34] and vaccines [35]. Currently, many efforts have been directed towards the development of effective vaccines and therapies to prevent transmission person-to-person, between health professionals or the elderly [36]. The fourth is based on the reduction of human risk by minimizing human behaviors and practices that increase the probability of agent's transfer and amplification. In relation to COVID-19, the main measures are wearing a mask, frequent hand washing, promoting social distance and compliance with lockdowns [37].

Due to COVID-19, public awareness has reached an unprecedented scale. In the face of the current pandemic, the public is required to understand and trust the entities that are making recommendations to limit the exposure and spread of the disease. General public must trust on science and collaborate with public health services through practicing all measures and policies implemented to solve the pandemic problem. The battle against COVID-19 has not yet been won, and people's adherence to prevention and control measures are essential to ensure ultimate success, including collaboration between veterinary and human medicine through the One Health strategy for prevention and control of COVID-19, as well as other emerging zoonosis.

\section{Conclusion}

Emerging infections have been responsible for several dark days of widespread suffering and death in human and animal history and will certainly continue to pose a serious challenge into the future. The collaborative efforts made worldwide in terms of diagnosis, quarantine, confinement, intensive care, vaccination and medicines with the collaboration of the population are fundamental and are beginning to bear fruit in the prevention and control of COVID-19. It is urgent to create task forces, networks and all types of collaborations between human and veterinary medicine, because the time is in countdown to the next zoonotic event. COVID-19 will not be the last pandemic and because of that the world needs to be prepared.

Funding: This study was supported by project UIDB/ CVT/00772/2020 funded by Fundação para a Ciência e a Tecnologia (FCT).

\section{References}

1. Serrano I, Gomes D, Ramilo D, Rebelo MT, da Fonseca IP, et al. (2019) An overview of zoonotic disease outbreaks and its forensic management over time. J Forensic Sci 64(5): 1304-1311.

2. do Vale B, Lopes AP, Fontes MC, Silvestre M, Cardoso L, et al. (2021) Bats, pangolins, minks and other animals - villains or victims of SARS-CoV-2? Vet Res Commun 45(1): 1-19.

3. Pal M, Berhanu G, Desalegn C, Kandi V (2020) Severe Acute Respiratory Syndrome Coronavirus-2 (SARSCoV-2): an update. Cureus 12(3): e7423.

4. Schoeman D, Fielding BC (2019) Coronavirus envelope protein: current knowledge. Virol J 16(1): 69.

5. Song Z, Xu Y, Bao L, Zhang L, Yu P, et al. (2019) From SARS to MERS, thrusting coronaviruses into the spotlight. Viruses 11(1): 59.

6. Çelik A, Yaman H, Turan S, Kara A, Kara F, et al. (2014) A brief guide to emerging infectious diseases and zoonoses. World Health Organisation.

7. Kobayashi N (2018) Impact of emerging, re-emerging and zoonotic viral infectious diseases, in a virologist's perspective. Open Virol J 12: 131-133.

8. Rahman MT, Sobur MA, Islam MS, Ievy S, Hossain MJ, et al. (2020) Zoonotic diseases: Etiology, impact, and control. Microorganisms 8(9): 1405.

9. Bloom DE, Cadarette D (2019) Infectious disease threats in the twenty-first century: strengthening the global response. Front Immunol 10: 549.

10. Murta FLG, Massara CL, Nogueira JFC, Dos Santos Carvalho O, de Mendonça CLF, et al. (2016) Ecotourism 


\section{Open Access Journal of Veterinary Science \& Research}

as a source of infection with schistosoma mansoni in Minas Gerais, Brazil. Trop Dis Travel Med Vaccines 2: 3.

11. Mangili A, Vindenes T, Gendreau M (2015) Infectious risks of air travel. Microbiol Spectr 3(5).

12. Chaber AL (2018) The era of human-induced diseases. EcoHealth 15(1): 8-11.

13. Perez AM (2015) Past, present, and future of veterinary epidemiology and economics: one health, many challenges, no silver bullets. Front Vet Sci 2: 60.

14. Uğur NG, Akbiyik A (2020) Impacts of COVID-19 on global tourism industry: a cross-regional comparison. Tour Manag Perspect 36: 100744.

15. Wells CR, Sah P, Moghadas SM, Pandey A, Shoukat A, et al. (2020) Impact of international travel and border control measures on the global spread of the novel 2019 coronavirus outbreak. Proc Natl Acad Sci U S A 117(13): 7504-7509.

16. Pasmans F, Hellebuyck T, Martel A, Bogaerts S, Braeckman J, et al. (2017) Future of keeping pet reptiles and amphibians: towards integrating animal welfare, human health and environmental sustainability. Vet Rec 181(17): 450.

17. OIE (2021) World Animal Health Information System. $34(8)$.

18. Patterson EI, Elia G, Grassi A, Giordano A, Desario C, et al. (2020) Evidence of exposure to SARS-CoV-2 in cats and dogs from households in Italy. Nat Commun 11(1): 6231.

19. Jansen W, Müller A, Grabowski NT, Kehrenberg C, Muylkens B, et al. (2019) Foodborne diseases do not respect borders: zoonotic pathogens and antimicrobial resistant bacteria in food products of animal origin illegally imported into the European Union. Vet J 244: 75-82.

20. Lauring AS, Hodcroft EB (2021) Genetic variants of SARSCoV-2 - What do they mean? JAMA 325(6): 529-531.

21. Rambaut A, Loman N, Pybus O, Barclay W, Barrett J, et al. (2020) Preliminary genomic characterisation of an emergent SARS-CoV-2 lineage in the UK defined by a novel set of spike mutations.

22. Galloway SE, Paul P, MacCannell DR, Johansson MA, Brooks JT, et al. (2021) Emergence of SARS-CoV-2 B.1.1.7 lineage. MMWR 70(3): 95-99.

23. Kurpiers LA, Schulte-Herbrüggen B, Ejotre I, Reeder DM
(2015) Bushmeat and emerging infectious diseases: lessons from Africa. Problematic Wildlife 21: 507-551.

24. Namusisi S, Mahero M, Travis D, Pelican K, Robertson C, et al. (2021) A descriptive study of zoonotic disease risk at the human-wildlife interface in a biodiversity hot spot in South Western Uganda. PLoS Negl Trop Dis 15(1): e0008633.

25. Wang LF, Crameri G (2014) Emerging zoonotic viral diseases. Rev Sci Tech 33(2): 569-581.

26. Cunningham AA, Daszak P, Wood JLN (2017) One health, emerging infectious diseases and wildlife: two decades of progress? Philos Trans R Soc B Biol Sci 372(1725): 20160167.

27. Vonesch N, Binazzi A, Bonafede M, Melis P, Ruggieri A, et al. (2019) Emerging zoonotic viral infections of occupational health importance. Pathog Dis $77(2)$ : ftz018.

28. Fouque F, Reeder JC (2019) Impact of past and ongoing changes on climate and weather on vector-borne diseases transmission: a look at the evidence. Infect Dis Poverty 8(1): 51.

29. Van Helden PD, Van Helden LS, Hoal EG (2013) One world, one health: humans, animals and the environment are inextricably linked - a fact that needs to be remembered and exploited in our modern approach to health. EMBO Rep 14(6): 497-501.

30. Osburn B, Scott C, Gibbs P (2009) One world - one medicine - one health: emerging veterinary challenges and opportunities. Rev Sci Tech 28(2): 481-486.

31. Morens DM, Folkers GK, Fauci AS (2004) The challenge of emerging and re-emerging infectious diseases. Nature 430(6996): 242-249.

32. Decaro N, Lorusso A (2020) Novel human coronavirus (SARS-CoV-2): a lesson from animal coronavirus. Vet Microbiol 244: 108693.

33. Schröder I (2020) COVID-19: a risk assessment perspective. ACS Chem Health Saf 27(3): 160-169.

34. Wei S, Kohl E, Djandji A, Morgan S, Whittier S, et al. (2021) Direct diagnostic testing of SARS-CoV-2 without the need for prior RNA extraction. Sci Rep 11(1): 2402.

35. Walsh EE, Frenck RW, Falsey AR, Kitchin N, Absalon J, et al. (2020) Safety and immunogenicity of two RNA-based COVID-19 vaccine candidates. N Engl J Med 383(25): 2439-2450. 


\section{Open Access Journal of Veterinary Science \& Research}

36. Chen WH, Strych U, Hotez PJ, Bottazzi ME (2020) The SARS-CoV-2 vaccine pipeline: an overview. Curr Trop Med Rep, pp: 1-4.

37. Coroiu A, Moran C, Campbell T, Geller AC (2020)
Barriers and facilitators of adherence to social distancing recommendations during COVID- 19 among a large international sample of adults. PLoS One 15(10): e0239795.

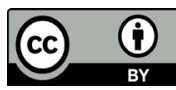

